\title{
The Conundrum of Demographic Aging and Policy Challenges: A Comparative Case Study of Canada, Japan and Korea ${ }^{1}$
}

\author{
Susan A. McDaniel, FRSC \\ University of Utah \\ susan.mcdaniel@ipia.utah.edu
}

\begin{abstract}
Some analysts lean toward comparative analyses of population aging, then draw potential policy implications. Others lean in the direction of attention to differences in policy regimes and then consider implications of population aging. Key differences among advanced societies may not emanate from demographic aging but from differences in how markets, states, and families work to redistribute societal benefits. In this paper, three countries with contrasting configurations of markets, states, and families, and at different stages of demographic aging, are compared and contrasted: Canada, Japan, and Korea. The paper has three objectives: 1) to outline key changes in population, family, and work in the three countries; 2) to consider how knowledge about these changes, their dynamics and interrelationships, is framed with respect to policy options; and 3) to compare Canada, Japan, and Korea in terms of the framing of policy challenges related to demographic aging. It is found that Canada is joining the longstanding pattern of Japan and Korea of late home-leaving by youth, meaning less effective time in the paid labour force. Little deep connection exists between population aging and economic productivity or labour force shortages. Differential labour market participation of women mediates the effects of population aging.
\end{abstract}

Keywords: comparative analysis, population aging, population policy, labour force

\section{Résumé}

Il y a des analystes qui ont un penchant pour les analyses comparatives du vieillissement des populations, puis en déduisent les implications possibles sur les politiques. D'autres préfèrent porter leur attention sur les différences dans les régimes de politiques, puis considèrent les implications sur le vieillissement des populations. Il est possible que les différences majeures dans les civilisations de pointe ne soient pas apparentes dans le vieillissement démographique

1. Revised version of a paper first invited for the Trilateral Social Policy Research Conference, Health Care, Work-Family Responsibilities and Income Redistribution in Diversified and Aging Societies, Tokyo, Japan, February 16-17, 2008, and then presented in the session, "International Perspectives on Population Change and Public Policy," Canadian Population Society, University of British Columbia, June 4-6, 2008. The paper has benefited from helpful comments from many colleagues in Canada, Korea, and Japan as well as suggestions made by $\mathrm{Zheng} \mathrm{Wu}$ and two anonymous reviewers. 
mais plutôt dans les différentes manières dont les marchés, les états, et les familles auvrent à redistribuer les avantages sociaux. Dans cet article, trois pays dont les marchés, les états et les familles contrastent et qui se trouvent à différents points dans le vieillissement des populations sont comparés et contrastés : le Canada, le Japon, et la Corée. Cet article a trois objectifs : 1) souligner les changements majeurs dans les populations, les familles, et la situation de l'emploi dans chaque pays ; 2) évaluer comment les données au sujet de ces changements, leurs dynamiques et leurs rapports mutuels, sont cadrées par rapport aux possibilités d'action; et 3) comparer le Canada, le Japon et la Corée dans leur cadrage des défis aux politiques posés par le vieillissement des populations. Il se dégage de l'étude que le Canada est en train de joindre le modèle déjà bien établi au Japon et en Corée des départs tardifs des jeunes, ce qui représente une plus courte période de temps au sein de la main d'œuvre rémunérée. De petits mais profonds liens existent entre le vieillissement des populations et la productivité économique ou les pénuries de main d'œuvre. La participation différentielle des femmes à la main d'œuvre affecte le vieillissement des populations.

Mots clés : analyse comparative, vieillissement des populations, politiques des populations, main d'œuvre.

In the quest to understand the conundrum of whatever policy challenges demographic aging may or may not pose, some analysts compare population aging or temporal age structural shifts, and then draw policy implications. This approach tends to overlook differences among policy regimes and how they structure life course patterns. Other analysts compare policy regimes and then consider what implications population aging may have for the sustainability of those regimes. In the demographic aging literature, insufficient attention has been paid to the ongoing interaction of population aging (including family and gender/generational changes) with shifting socioeconomic contexts and policy regimes. Key differences in how societies manage, or could manage, demographic aging in policy terms, may not emanate from demographic change nor from the organization of policy regimes, but more from the ways in which markets, states, and families dynamically interact to produce and distribute/redistribute the benefits of society. In this paper, three countries at different stages of demographic aging and with contrasting configurations of markets, states, and families, are compared and contrasted as case studies.

The three countries that are the focus of this paper, Canada, Japan, and Korea, are all demographically aging but are at very different stages in the process, with different paces of aging. All are experiencing family and work changes as well as policy changes and challenges of varying sorts. Focusing on these three countries affords an opportunity to enhance existing understandings of the relationship of demographic aging and policy challenges in contexts of wider global socioeconomic change. The paper has three objectives: 1) to compare key changes in population, family, and work in the three countries; 2) to consider how knowledge about these changes, their dynamics and interrelationships, is framed with respect to policy options or 
potential options; and 3) to compare Canada, Japan, and Korea in terms of the framing of policy challenges related to demographic aging.

\section{Aging and Diversifying Populations}

Canada's population continues to age, but remains one of the youngest among the world's developed nations (Statistics Canada, 2007a). Canada is number 22 on the world's list of oldest countries with $13.1 \%$ of its population aged 65 and older in 2005, Japan is the demographically oldest country in the world with $20 \%$ age $65+$. Korea, in 2005, is 28th (only 9\% 65+), as shown in Table 1. In the period 2002 to 2007, the median age in Canada rose from 37.6 years to 39.0. The median age in Japan in the same 5 year period increased from 42 to 43.5; in Korea, from 33.2 to 35.8. Table 1 shows, however, that the pace of population aging in Korea over coming decades is such that it will almost catch up with Japan by 2050, and will far outpace Canada, assuming continuation of recent rates of fertility, reductions in mortality and net immigration.

\begin{tabular}{|c|c|c|}
\hline Country and rank & $2005 \%$ & $2050 \%$ \\
\hline 1- Japan & 20.0 & 39.6 \\
\hline 2- Italy & 19.6 & 33.7 \\
\hline 3- Germany & 18.9 & 29.6 \\
\hline 22- Canada & 13.1 & 26.3 \\
\hline 23- Australia & 13.1 & 25.7 \\
\hline 24- United States & 12.4 & 20.6 \\
\hline 25- New Zealand & 12.1 & 26.2 \\
\hline 28- Korea & 9.1 & 38.2 \\
\hline 29- Turkey & 5.9 & 17.0 \\
\hline 30- Mexico & 5.3 & 21.1 \\
\hline
\end{tabular}

What are the processes by which demographic aging is occurring in the three countries? Key demographic indicators are shown in Table 2. In short, the population pyramids of all three countries, as shown in Figures 1 and 2, are moving from lantern-shaped for Canada and Japan, and pyramidal for Korea in the 2000s, to tubular for all three by 2025 (not shown), to topheavy tubular by 2050 . The most dramatic demographic change occurs in Korea, where a very low birthrate, comparable to that of Japan, combined 
Table 2. Selected Demographic Indicators 2008, 2025

\begin{tabular}{|c|c|c|}
\hline & 2008 & 2025 \\
\hline \multicolumn{3}{|l|}{ Canada } \\
\hline Population growth rate & 0.8 & 0.6 \\
\hline Total Fertility Rate & 1.6 & 1.6 \\
\hline Life expectancy & 81 & 83 \\
\hline \multicolumn{3}{|l|}{ Japan } \\
\hline Population growth rate & -0.1 & -0.7 \\
\hline Total Fertility Rate & 1.2 & 1.4 \\
\hline Life expectancy & 82 & 83 \\
\hline \multicolumn{3}{|l|}{ Korea } \\
\hline Population growth rate & 0.4 & -0.1 \\
\hline Total Fertility Rate & 1.2 & 1.3 \\
\hline Life expectancy & 77 & 82 \\
\hline \multicolumn{3}{|c|}{$\begin{array}{l}\text { Source: US Census Bureau, International Data Base. 2008, http://www.census.gov/ipc/ } \\
\text { www/idb/country/caportal.html }\end{array}$} \\
\hline \multicolumn{3}{|c|}{ Note: Immigration assumptions: } \\
\hline & Rate (per 1K pop) & \#'s (2008-2025) \\
\hline Canada & 6 & $187 \mathrm{~K}$ to $214 \mathrm{~K}$ \\
\hline Japan & 0 & close to 0 \\
\hline Korea & -1 to -2 & $-32 \mathrm{~K}$ to $-81 \mathrm{~K}$ \\
\hline
\end{tabular}

with rapid improvements in life expectancies, means that Korea is aging with remarkable speed.

Demographic processes such as population aging do not occur in a vacuum but are the consequence of socioeconomic development. South Korea and several other East and Southeast Asian countries have set the gold standard for economic development, even taking into consideration the mid to late 1990s downturns (Ikeda and Kim, 2000). This is evidenced by a dramatic average annual growth in GDP per capita of $6.9 \%$ in Korea in the 1960-1990 period, a 17 year increase in life expectancy, and a substantial decline in the total fertility rate (TFR) of 4.3 births per woman (McNicoll, 2006). In comparison, China's annual growth in GDP per capita in the 1970-2000 period was $4.9 \%$.

Canada's population growth rate is higher than that of both Japan and Korea for two reasons. One is clearly evident in Table 2: a higher TFR in Canada than in either of the two comparison countries. The other is Canada's significant immigration, particularly when compared to Japan and Korea, both of which continue to have very low to nonexistent levels of immigration. Korea, over the coming years, is likely to experience significant emigration. Recent research (Seol, 2008) points out that Korea in August 2007 had one million foreign-born residents, but Korea remains, as Seol argues, "a country of sojourn," not one of immigration per se. 


\section{0}
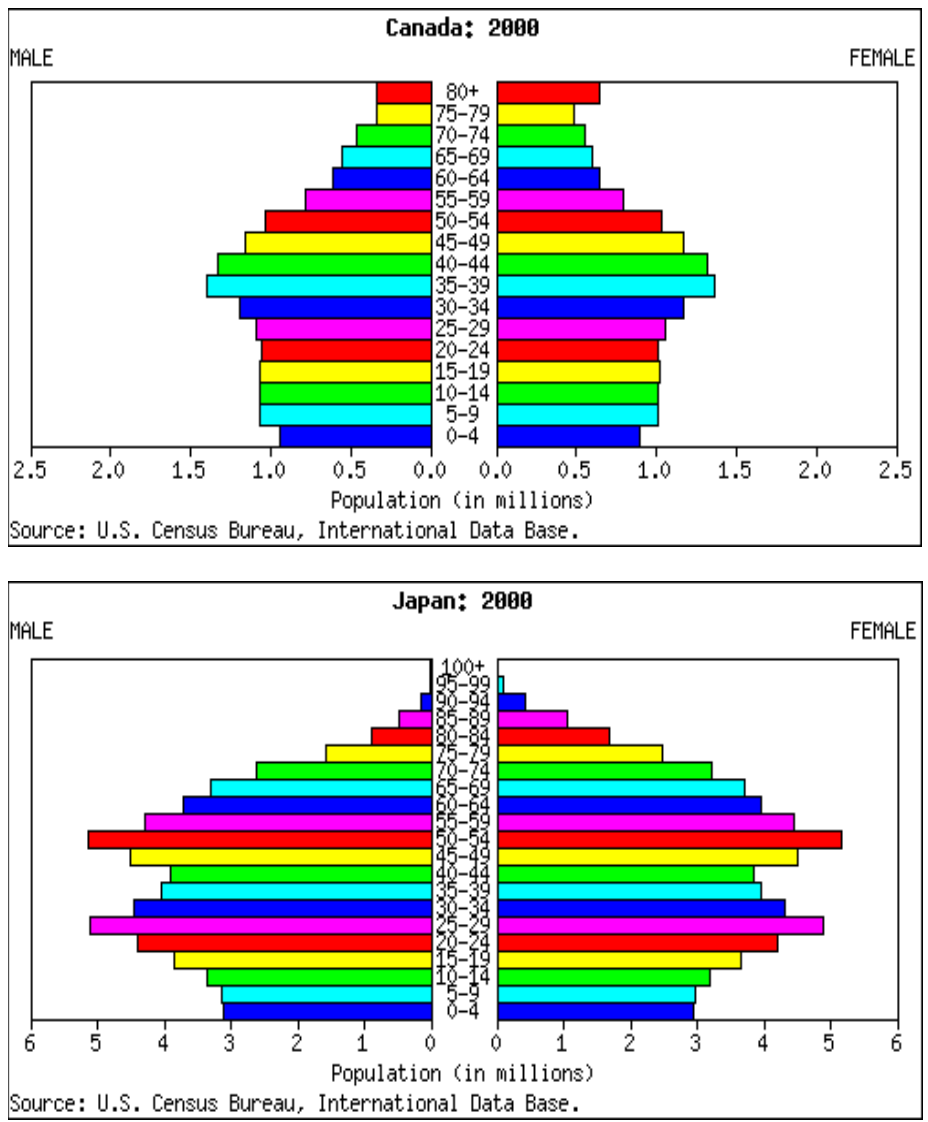

Source: U.S. Census Bureau, International Data Base.

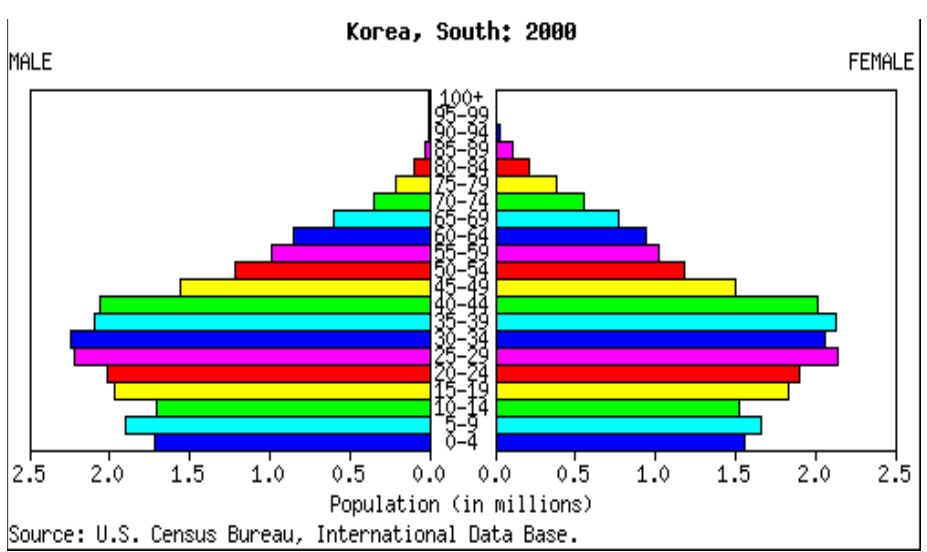




\section{0}

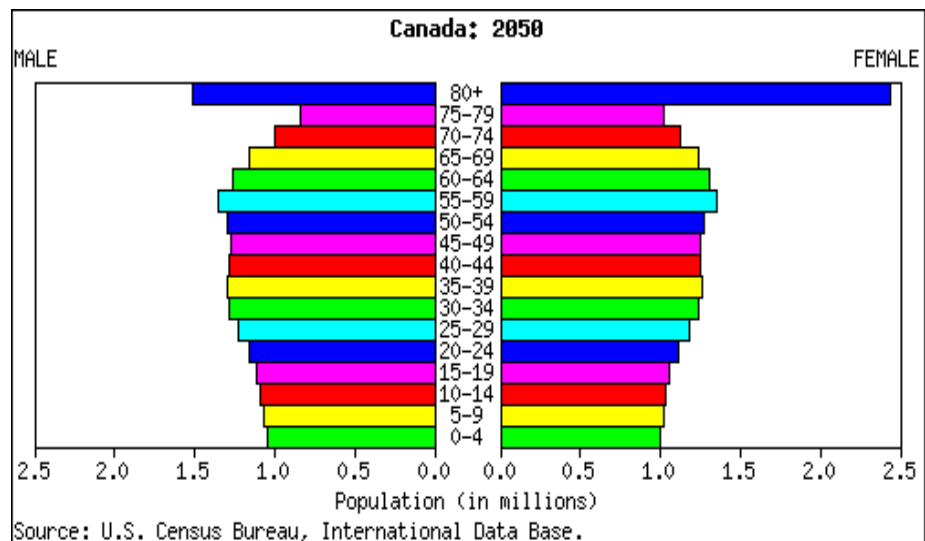

Source: U.S. Census Bureau, International Data Base.

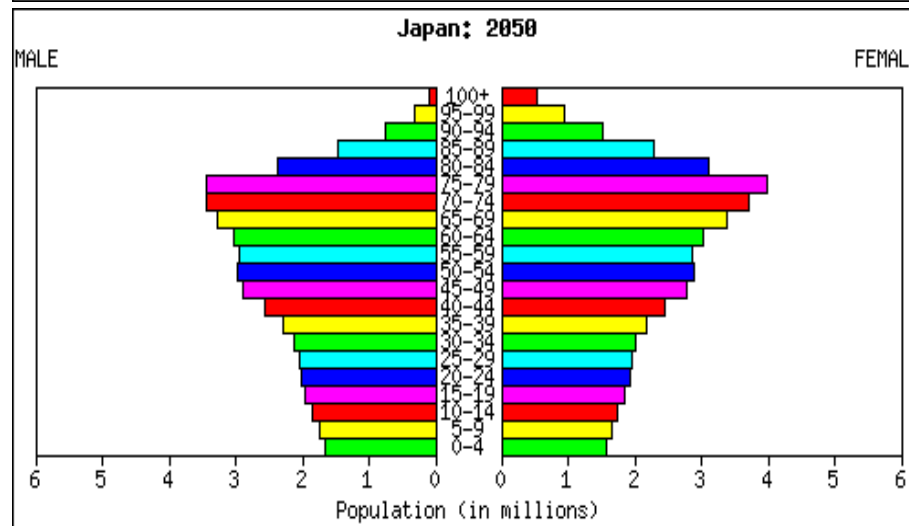

Source: U.S. Census Bureau, International Data Base.

\begin{tabular}{lll}
\hline \hline MiLLE & Korea, South: 2050 & \\
\hline
\end{tabular}

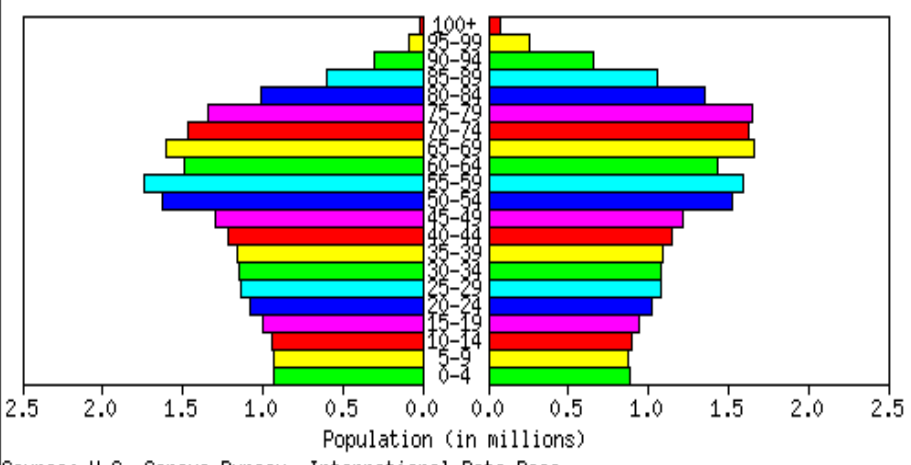

Source: U.S. Census Bureau, International Data Base. 
We now turn to the contextual forces and factors contributing to demographic aging in the three countries comprising this case study.

\section{Family Changes}

Family changes are always part and parcel of demographic change, and fundamental to demographic aging. The central contributing cause of demographic aging is reduced fertility, a family phenomenon. But other factors create lower fertility and population aging. Three salient family changes occurring in all three countries, to varying degrees, are highlighted here: working mothers, home-leaving, and living arrangements of older adults.

\section{Working mothers}

In recent decades, in most OECD countries, there has been a substantial growth in women's employment (OECD, 2005). Several factors contribute to this trend, including rising living costs, increased marital instability, declining "family wage," pursuit of gender equality, strengthening of women's rights, and changing government policies enabling the balancing of paid work with family.

Although Canada, Japan, and Korea have all seen growth in women's labour market participation, the trend is strongest by far in Canada. Women no longer leave paid work in Canada when they marry as they did before World War II, and still do, to a degree, in both Korea and Japan (Ochiai, 2005; 2008). Most significantly, the presence of children, even preschool age children, is less and less deterring Canadian women from paid labour market activity. Indeed, the largest increase over the last two decades is in employment of married mothers with children under age 5 (preschool) (Statistics Canada, 2007c). With lone mothers of preschool children, there has been a less dramatic increase in paid work. However, once the children of lone mothers enter school, paid work among these mothers increases significantly (Statistics Canada, 2007c). This suggests that the challenge for lone mothers working outside the home may be affordable quality childcare.

Increases in paid employment for married women and mothers, however, does not mean equality either in income or in sharing responsibilities at home. Canadian women still earn less than men, and still tend to cluster in "female oriented" jobs that are lower paid than men's jobs, such as clerical, retail, public school teaching, etc. Occupational segregation by gender remains alive and well in Canada, despite strides made by some women into male and higher prestige occupations (Statistics Canada, 2006c). 
What these changes mean for an aging Canada is more women with pensions, although often not good pensions on which they can comfortably live, and greater challenges in caring for both young and old. The pension plan coverage and retirement savings of working-age couples over the last two decades in Canada, with the substantial growth in wives' labour market participation and the slight increase in their registered pension plan coverage, only partially offset a substantial decline in husbands' coverage (Statistics Canada, 2008).

Japan's labour force is much more strongly gender-segregated, with fewer women in the paid workforce and a larger gender gap in pay than Canada. It has been noted, in comparative studies of Japan with other major developed countries, that there has been little change over the past 25 years in women's labour market participation (Ochiai, 2005:4). Ochiai (2008) describes the long-term persistence of the "M" curve of Japanese women's labour market participation, where women depart from the workplace when they have children at home. Japan has a special category of worker by policy, called "family workers" who are differentially women. In the mid-1990s, almost 3 million Japanese women (or 12\% of the approximately 25 million women in the paid labour force) were in this category (Clement, 2001: Japan Statistics Office, 2008). The concept is that working mothers are in less demanding occupations where they can combine work with family, or alternatively, can anticipate leaving work when they have children. The pay for "family workers" is less, often very much less, than for "regular" labour market participants.

Korea is more like Japan than Canada in the level and age patterns of women's labour force participation (Ochiai, 2008; Choi, 2008a; 2008b). In fact, the labour market participation of Korean women is the lowest of all OECD countries (OECD, 2005). More recent cohorts of women have more sustained paid labour market participation, but still notably less than men. Korean women, like Japanese women, experience a strong dip in labour market participation in prime childrearing ages, the " $\mathrm{M}$ " pattern mentioned above. Choi (2008a:2) suggests that "it is a harsh reality that women's role in childbirth (reproduction) is a huge disadvantage in economic activities in Korea."

Women postpone childbearing in Korea significantly in order to insure that they have a stable job before having children. This results in smaller family sizes and accounts in part for the very low Korean TFR.

\section{Home-leaving}

One very pronounced recent family change in Canada is in home-leaving, or more precisely, home-not-leaving, by adult children (Myles, 2007). 
Young Canadian adults are taking much longer to leave the parental home than their parents did. Those in the so-called Generation X, especially those born between 1972 and 1976, are three times as likely to return home to live with their parents as the baby boomers (born 1946-1966) were (Statistics Canada, 2006b). Indeed, the tendency to return home at least once by these so-called "boomerang children" has increased in each of five successive cohorts, starting with the first wave of baby boomers who were born between 1946 and 1951 (Statistics Canada, 2006b). A number of factors may explain this growing Canadian trend including the increasing instability of early conjugal unions, the pursuit of higher education which tends to leave young graduates with heavy student debts, financial difficulties, the reduced stigma attached to living with one's parents, seeking a standard of living impossible to attain on one's own, the new and different roles of parents and children in families, and seeking a parent's emotional support during the increasingly stressful transition to adulthood.

The implications of the home-leaving/home-returning trend in Canada are multiple. If it takes young adults longer to achieve independence, leaving school later, staying longer in their parents' home, entering the labour market later (although some youth may be working for pay while living in the parental home), and postponing conjugal unions and childbearing, they will have fewer years in which to have children, hence smaller family sizes. This is certainly the pattern in Italy, with the record for the longest time for adult children to live in the family home, and in the 1990s, the smallest family sizes in Europe (Kohler, Billari and Ortega, 2002). Adults who live with their parents longer also have fewer years to contribute to their future pensions, although there is yet little evidence on this. The parents may also have lower retirement savings because of the support they provide to their adult offspring. All of these factors mediate between population aging and policy.

In Japan and Korea, the predominant East Asian pattern of adult children living with parents has prevailed. In Japan in the 1970s, for example, $15 \%$ of males and $14 \%$ of females lived with their parents up to age 40 (Zeng et al., 1992). Some of these older offspring may be supporting or helping to support their older parents. Perhaps because of the tendency for adult children to live with parents longer in East Asia, the phenomenon has not received as much recent attention as it has in Canada. Nor may it have the same implications for policy and intergenerational exchanges because the patterns are longer standing than in Canada. However, living with one's parents is an effective contraceptive. Postponing the establishment of unions, and of childbearing, contributes to reduced fertility and hence to population aging. Parents supporting adult children for lengthy periods of 
time may have less for their own old age. Recent reductions in fertility may be explained more in Japan and Korea in terms of the escalating costs of establishing one's own home and family.

\section{Living arrangements of older adults}

Even in societies with strong traditions of older parents living with children, such as Japan and Korea, traditional living arrangements are becoming less common (Shirahase, 2008; Ogata, 2008), although adult children taking in older relatives is still the dominant pattern in both countries. In the past, living alone or at least not with one's adult children in old age was often equated with social isolation or family abandonment. However, research in many cultural settings shows that older people, even those living alone, prefer to be in their own homes and communities. This preference is reinforced by greater longevity, expanded social benefits, increased home ownership, elder-friendly housing, and an emphasis in many countries on community care (National Institute of Aging, 2007:17). Mobility of workers, including global mobility, also means that aging parents are less often living in close proximity with their adult children.

In the 2001 Census of Canada, there were about as many one-person households as there were households with four or more people (Statistics Canada, 2002). This includes many more older persons living alone. This does not mean, however, that these elders are without social connections. Many maintain active and ongoing relationships with family members and friends, but choose to live alone. In part, this is a function of being able to afford the option of doing so. It is also related to the overall good health of Canadian older adults. There are some differences, however, between Canadian-born and foreign-born Canadians in living arrangements in later life. More immigrant elders tend to live with their adult children (Statistics Canada, 2007d). The motivation of having children to provide care in one's later years seems to remain a factor in some immigrant communities in Canada. This parallels the risk insurance for old age children have provided in East Asian societies for generations. For both immigrants in Canada whose fertility drops as they live in Canada, and for the East Asian societies of Japan and Korea, reliance for old age is on diminishing numbers of children.

\section{Work Changes}

Demographics alone suggest that the share of workers aged 50 and older in the total labour force will increase between 2000 and 2050 in every OECD 
country (Canada, Policy Research Initiative, 2005). When this trend is combined, however, with the trend to early retirement of recent decades (recently reversed in Canada for men, although not among women, as well in some other OECD countries), the challenges of changing work participation, by age, become more acute (Bowlby, 2007). Accentuating the challenge are reduced birthrates, resulting in fewer new workers entering the labour market in the future, together with delayed entry of contemporary young adults. With a smaller pool of entering workforce participants, there is need for generational communication from older workers to those younger to ensure the transmission of generational knowledge and continuity, as well as generation of income to support those who are retired.

Patterns of workforce withdrawal by older workers are notoriously difficult to compare and predict, contingent as they are on national patterns of workforce behaviours, finances, pension availability, and the ways in which work is structured in societies (American Association of Retired Persons, 2007). In Canada, for example, the pattern of early retirement shown in Table 3 has reversed in recent years. Older workers are staying in the workforce longer, which may dampen the threat of a sudden labour shortage as baby boomers retire (Statistics Canada, 2007b). The majority of individuals in their late 50s were still working in Canada in 2005. Among men aged $55-59$, three-quarters $(76 \%)$ either had a job or were looking for one. This rate was below the 1976 high of $84 \%$, but above the 1998 low of $71 \%$ (Statistics Canada, 2007b). A smaller proportion of people aged 60-64 were in

Table 3. Effective and statutory retirement ages in selected OECD countries

\begin{tabular}{|c|c|c|c|c|c|c|}
\hline & \multicolumn{2}{|c|}{ Effective Retirement Age } & \multicolumn{2}{|c|}{ Statutory Retirement Age } & \multicolumn{2}{|c|}{ Difference } \\
\hline & Men & Women & Men & Women & Men & Women \\
\hline Japan & 70.0 & 66.2 & 65 & 65 & 5.0 & 1.2 \\
\hline U.S. & 64.7 & 63.6 & 65 & 65 & -0.3 & -1.4 \\
\hline Denmark & 64.3 & 60.6 & 65 & 65 & -0.7 & -4.4 \\
\hline Sweden & 63.8 & 62.5 & 65 & 65 & -1.2 & -2.5 \\
\hline Canada & 62.8 & 60.8 & 65 & 65 & -2.2 & -4.2 \\
\hline U.K. & 62.4 & 60.9 & 65 & 60 & -2.6 & 0.9 \\
\hline Australia & 61.9 & 59.7 & 65 & 61 & -3.1 & -1.3 \\
\hline Netherland & 60.7 & 59.0 & 65 & 65 & -4.3 & -6.0 \\
\hline Finland & 60.1 & 59.7 & 65 & 65 & -4.9 & -5.3 \\
\hline France & 59.6 & 59.7 & 60 & 60 & -0.4 & -0.3 \\
\hline OECD & 63.0 & 61.3 & 64.8 & 63.8 & -1.9 & -2.4 \\
\hline \multicolumn{7}{|c|}{$\begin{array}{l}\text { Note: The effective retirement age relates to the average age at which persons aged } 40 \text { and over left the labour force } \\
\text { during the period 1995-2000. The statutory pension age refers to the earliest age at which workers are entitled to a } \\
\text { full State Pension. Average for available countries. }\end{array}$} \\
\hline Source: OECD & 2008) & & & & & \\
\hline
\end{tabular}


the labour force; since 2005, both men and women have made recent gains. In $2005,53 \%$ of men age $60-64$ were in the workforce, compared with only $43 \%$ in 1995 . A record $37 \%$ of women in this age group were still working.

The Canadian rise in labour force participation among older workers is predicted to continue for three reasons: a strong attachment to the labour market among baby boomers, both men and women; rising levels of education, particularly among women; and a desire among people over 55 to continue working, out of interest, financial concern, or other factors, such as the virtual elimination of mandatory retirement in Canada. A shift is apparent in 2006 toward nonstandard work arrangements among older workers, such as self-employment, suggesting that some are making a conscious transition towards retirement. It is also clear that in Canada retirement is being redefined, with significant numbers of older workers taking private pensions but working at the same time, most often at new jobs. This trend away from the tripartite life course of education, work, retirement parallels many OECD countries.

Japan offers an interesting contrast with Canada on patterns of withdrawal from the workforce, although direct comparisons are nearly impossible. Japan has developed a complex approach to "exit paths" from paid employment, perhaps a precursor to the move, in all OECD countries, away from the traditional work until retirement "Gold Watch" life course pattern (Bernard and McDaniel, 2006; Ikeda, 2002). Retirement in Japan is a complicated set of various options including buy-outs, transfers, phased retirement, etc. There are few men who actually remain in full employment until official retirement age (Clement, 2001). The implications of this diverse pattern of labour market participation among older workers in Japan are not fully known.

In Korea, a sharply polarized labour market has emerged since the economic crisis of 1997 (Choi, 2008b). Polarization has occurred in both wages and job security. Those who have secure jobs with benefits, including pensions, can plan for retirement. At the same time, a large and growing category of insecure, irregular workers have difficulty making ends meet, never mind planning for retirement. In fact, temporary employment and day-to-day employment have replaced secure jobs (Choi, 2008b). Combined, there are more people in temporary and day-to-day employment in Korea than in secure jobs, according to the Korean Statistical Office (Choi, 2008b:12). "Labor market flexibility in Korea is much higher than many other countries, almost close to the United States" (Choi, 2008b:16). The financial crisis and involvement of global agents/forces in the situation of Korea since 1997 has meant vastly increased insecurity for many in the labour market, and an incapacity of existing social policies to deal with 
the situation. Population aging pales in relation to the magnitude of these challenges.

The impact of population aging on productivity performance remains a question in need of further research. A survey of what is known about this (Praeger, 2002) concludes that the evidence is mixed, differs from the individual to the aggregate level, and from sector to sector. Productivity is also a political and policy question, and must be examined contextually (McMullin, Cooke, and Downie, 2004). Leaping from the individual level, i.e., concerns about declines with individual aging, and applying that without consideration of the societal level issues, is perilous. Productivity of any workforce is highly contingent on capital and human capital investments and shifts in policies and attitudes in the workplace. That there is little deep connection of population aging with productivity or labour force shortages is made very clear by McMullin, Cooke, and Downie (2004). Challenges to productivity or labour force in terms of feared shortages are not linearly determined by population aging per se, but the result of a complex set of socioeconomic factors and forces, including vital mediating factors such as who is fully employed McDaniel, 1987; 2005; Veron and Pennec, 2007).

\section{Framing Knowledge as Capacity to Act}

Secular demographic, family, and work trends and patterns are not passive. Knowledge embodies the capacity to act (Stehr and Meja, 2000). Knowledge changes the way we see the world, the way we live in it as individuals and as societies, and the ways policies are developed built on that knowledge. It has been remarked that once we saw the globe, from space, as a real globe with forests, oceans, and continents clearly visible, we could no longer disconnect ourselves from what occurs in other countries and continents. As C.P. Snow aptly noted about scientists, " [they] have the future in their bones." Knowledge becomes part of ourselves and the way we see ourselves and our country/world. In Canada, Korea, and Japan, there are not only different demographic trends and tendencies, and different socioeconomic contexts, but differing relationships of knowledge to policy action, of knowledge as capacity to act.

Knowledge about demographic, family, and work changes is not merely insight on what is happening in a given society, it is also the becoming of a society. Knowledge of demographic, family, and work change is, in other words, reality altering. This may well contribute to the particularly intense concerns in Japan about low fertility, population aging, and negative population growth. Demographic knowledge has the capacity to alter the way citizens see their society. 
Max Weber (1949) taught that knowledge plays an active role only when room exists (or is made available) to take action on that knowledge. Karl Mannheim (1952) contributed the insight that deployment of knowledge in specific situations necessitates a connection between potential for action and understanding the available room for action. Research or evidence-based knowledge gains distinction in its capacity to change reality. The key is seeing which elements of a given situation are fixed and which ones open to action, in this case policy action. To assess that, contexts matter greatly. Here, the contrasting experiences of Canada, Japan, and Korea in acting on knowledge about population aging are instructive.

\section{Policy Challenges in Relation to Demographic Aging}

Policy challenges are determined not by demographic structures and changes per se but by the flow and interaction of multiple shifting processes, demographic, economic and social, national and global, in contexts of other policy priorities. Sociohistorical moments, sociocultural custom and practices, geopolitics, and importantly, generational expectations are key factors. The economic gain from large numbers of young workers, or conversely, the presumed economic loss from large numbers of retirees, for example, critically depends on the ways in which knowledge about these trends is framed for the policy environment. The capacity of the society, through policy and economics, to provide productive work for those entering the labour market, and financial sustenance for those who are retired, i.e., decommodified, largely determines the relationship of demographics to overall societal well-being in any society.

Demographic aging, as we have seen, is a product of human progress, an aggregation of individual choices or nonchoices to have fewer children, and to provide increasingly good standards of living so as to increase life expectancies for the majority. Population aging is an accompaniment to socioeconomic development. According to demographic transition theory, populations transition from Stage I through to Stage IV over time, but the time spent in each stage can vary significantly depending on the particular population being considered. A country can even get "trapped" in a stage if conditions are not right for the next transition. The four stages are easily defined: population growth is equal to births minus deaths plus immigration minus emigration. In stage I, high birth rates and high death rates result in small positive growth. Stage II sees high birth rates and falling death rates resulting in increasing growth, while stage III has falling birth rates and low death rates resulting in reduced growth. Stage IV has low birth rates and low death rates with small positive growth. Some countries with advanced 
population aging, such as Japan, indicate an additional stage in the theory with low birth rates and increasing death rates resulting in negative growth.

As a Stage V country, Japan is in an almost unique position of negative population growth. Russia is similarly losing population but for very different reasons. The pervasive sense of crisis over the falling birth rate and "aging society" issues has generated an active public debate in Japan about gender, the family, the organization of the workplace, and the best policy approaches for addressing the challenges (Boling, 1998; Shorto, 2008). This is a clear example of knowledge as capacity to act. Japan, in this sense, offers an interesting study in how a major political and economic power, with distinctive traditions, social values, understandings of statesociety relations, and policy processes addresses policy challenges that are simultaneously demographic and socioeconomic.

\section{The Framing of Policy Challenges in the Three Countries}

In response to concerns about the falling fertility rate, the major contributor to demographic aging, the Ministry of Health and Welfare in Japan launched an emergency five-year plan in 1994 to improve daycare services, which was broadened in 1995 to a ten-year plan pursued in conjunction with the Labour, Construction, and Education Ministries (Boling, 1998). New child-care leave policies were established that enable either parent to take leaves from paid work to care for children. This policy response recognizes the reality of the Japanese workforce; women depart when they have families as a result of the highly gendered family structure and expectations and the similarly gendered workplace. This framing of a policy response to the challenge of demographic aging recognizes that labour shortage concerns cannot be addressed when a significant proportion of potential labour participants, women in prime economically productive ages, drop out of the paid labour market. Demographer Billari is quoted in Shorto (2008:40):

\footnotetext{
Japan is just about as low [in birthrate as southern European countries].... All these societies are still rooted in the tradition where the husband earned all the money. Things have changed, not only in Italy and Spain but also in Japan and Korea, but those societies have not yet adjusted. The relationships within households have not adjusted yet.
}

Policy attention in Japan is devoted to eldercare, although eldercare is defined more as a private than a public responsibility. This is premised on a similar version of feminine caring prevalent in Canada and Korea as well as in many other countries. Yet, this version of presumed feminine caring is 
challenged in Canada, less so in Japan and Korea, by the very high labour market participation of women.

Gender ideologies compete in varying ways across countries, with modern social policies promoting paid work and opportunities for women as well as men. Policy originators in Japan, in contrast to those in Canada, tend not to be activists or policy researchers, but intelligent, well-read bureaucrats who focus on the "tea leaves" of trends and public opinion to develop what they see as beneficial policies. This represents a particular policy action process based on knowledge, which has unquestionable advantages and drawbacks. In the male-dominated workplace, problems faced by women wishing to take parental leaves, or facing various forms of structural impediments to acceptance as full labour market participants, are less readily seen or appreciated by policy bureaucrats who view these problems as outside the purview of their policy actions. Knowledge in this case, as capacity to act, may be constrained by the very forces that worked to galvanize postwar reconstruction in Japan, i.e., homogeneity of effort for the good of the country that promoted nationalistic social cohesion. Now, however, what Ikeda (2007) calls the "singular value orientation toward "material/money" may be detrimental to innovation and solving the current economic challenges. Peng (2008) echoes this, arguing that, for Japan, fear of change to traditional family/gender structures and practices as well as anxiety about foreigners may impede forward movement in both policy and economic development.

Japan's active and highly successful pursuit of economic growth to the detriment of developing domestic social infrastructure including policy, means that actions emanating from knowledge about demographic changes may mitigate against solutions, a situation exacerbated by current neoliberalism (Ikeda, 2004). Examples include the lack of adequate public green space for children to play, limited leisure places for families, housing options that cannot accommodate caring well for either young or old, and adherence to unworkable family and gender structures. The question is whether Japan can reinvent itself once again, this time delivering the humanistic (Ikeda, 2004) "goods" promised by corporate society.

The economic situation in Japan is the wider context for policy challenges framed by knowledge of demographic aging. Demographic aging may be a diversionary issue in the face of serious economic challenges, ongoing for more than two decades in Japan, and exacerbated recently by ripples from the current U.S. downturn. Ikeda (2004) argues compellingly that the economic crisis in Japan was a creation of two parents: application of misconstrued economic policies by Japan, and the U.S. policy of yen appreciation. The experience of a created asset bubble in Japan in the late 1980s and 
early 1990s, is almost a precursor of the current U.S. economic crisis.

Korea's framing of knowledge of demographic aging has been different. Problems with polarization of workers, with an economy challenged by global forces and a serious downturn in the 1990s, are well recognized. Now, Korea also sees a window of opportunity, a capacity to act in policy terms. On that knowledge, Korea, the youngest of the three countries in this case study, is the only one of the three to develop long-term public care insurance for elders (Kwon, 2008). Korea spends only about $6 \%$ of GDP on health at present and has been more successful than many OECD countries with health care cost containment (Kwon, 2008; Ogata, 2008). It is also recognized in Korea that population aging is not a major factor increasing health care costs overall, but that fundamental reforms are needed to address the needs of an older population. This knowledge led to the policy action of reducing the number of aged in the acute care system by providing publicly sponsored long-term care insurance. Despite its economic challenges with an increasingly insecure workforce who are finding it difficult to plan for later life, knowledge of its demographic and health care situation has enabled Korea to innovate in terms of policy action.

Canada, in comparison, is in a relatively strong public financial situation although there can be little doubt that with economic woes in the U.S., Canada will feel the shivers. With respect to the Canada/Quebec Pension Plan, however, the International Monetary Fund and the most recent Actuarial Report of the Chief Actuary of Canada indicate that the recent reforms to the C/QPP are sufficient to achieve a sustainable and sound CPP system for the next 75 years. This is in sharp contrast to the U.S. public pension situation, and that of several other countries. That said, there has been a drastic shrinkage in private pension availability and, with changes in work situations, a lessening of those even eligible for private pensions. There is also concern about a decline in public services, particularly the length of waiting lists in the Canadian health care system - which is publicly insured, although not public in terms of medical practitioners or other services. This has led to fears about the emergence of a two-tier system where better-off Canadians can "buy" private health care services or buy health care offshore. Declining urban infrastructure in Canada's largest cities, as well as concern about reductions in social services, both have implications as Canada's population ages.

Canada all too often bogs down policy discussion in inaction by the breadth of its consultations and the extent to which pressures from various interest groups are purportedly balanced. Knowledge, even if policyrelevant, is often mothballed, and not converted into action. The policy initiative of year-long parental leaves for either parent is an exception. With 
respect to child care, however, the political reach has far exceeded policy action, even though the knowledge needed for action on this front has been on the table for multiple decades.

Several recent initiatives aim to link demographic, family, and work changes to policy actions and options. The Policy Research Initiative (PRI) was created to introduce "horizontality" into the policy-development process. It was thought that issues were "siloed" in ministries and not considered in the broad contexts in which the policy challenges, in reality, took place. The new millennium saw the emergence of The Trends Project by the PRI, in partnership with the Social Sciences and Humanities Research Council of Canada, with three objectives: 1) to support the creation, sharing, and use of policy research knowledge; 2) to strengthen policy research capacity in departments through the recruitment, development, and retention of people; and 3) to build a policy research community through networks, vehicles, and venues (Cheal, 2002:ix). ${ }^{2}$ One of The Trends Projects was on Aging and Demographic Change in Canadian Context (Cheal, 2002) which came to three overall conclusions: 1) older people may not be a distinct demographic category with shared attributes but, in fact, a diverse category (increasingly so) with multiple interlinkages with other age categories (McDaniel, $2002)$; 2) that policies need to attend to the full range of interactions and links among demographically older populations with other age categories, including those that, occurring in families, may not be as visible as public transfers; and 3) new policies should be developed with respect to the life course as a whole rather than focused on a particular demographic category. For example, as has been seen above in the case of Japan, the development of a policy agenda with respect to children and women of childbearing age, deeply connects with policies affecting those who are older.

The Trends Project process resulted in deepening connections between academic research and researchers and policy people in Canada. One legacy, although it may not have been a direct outcome of the Project, was the development, through a lengthy process, of strategic knowledge clusters in Canada. These are groupings of academic researchers and policymakers, working together to develop a policy-relevant research infrastructure that enhances the capacity for networking, policy relevant research, training, and deeper connections of knowledge to policy action. One such cluster is the Population Change and Life Course Cluster, now funded for 7 years for C\$2.1 million. This cluster has identified policy challenges which place demographic issues in wider socioeconomic contexts, particularly life course contexts. Building life course into demographic analysis may not

2. Cheal was the leader of the Trends Project on Aging and hence the editor of the summary volume. 
be new but in policy research it is contributing fresh ways to see policy challenges.

What does the experience of Canada tell us about framing knowledge about demographic aging as capacity to act in policy, the key question of this paper? Three conclusions seem appropriate: 1) demographic analyses offer good evidence for policy, but taken alone, tend to be limited in pointing to specific policy actions; 2) demographic changes are aggregated human and institutional outcomes, deeply connected with social, economic, and life course changes; and 3) interactions and interconnections of socioeconomic changes with demographics determine policy action. There is a need for integrative policy to illuminate analyses of demographic changes taken together with socioeconomic and life course changes. This may be the key to unveiling social and economic development policy levers. Crucially, demographic aging is both cause and consequence of shifting socioeconomic forces (both national and global) and of individual choices in the face of constraints.

Most recently in Canada, the Institute for Research on Public Policy (IRPP), an independent policy institute, undertook a highly innovative exercise (Leonard, Ragan, and St.-Hilaire, 2007) with the goal of contributing to a broad-based and informed (key to this paper's focus on knowledge as capacity to act) public debate on policy choices and priorities for Canada. Fourteen issues were raised initially and then winnowed down to eight, including, "addressing the economic and social implications of an aging population." The socioeconomic implications of population aging per se did not emerge as a top policy priority, although it is in the top eight. Two policy issues loosely related to population aging emerged as low priorities, including improving the credential recognition for immigrants, increasing the training of medical practitioners in problems of aging, and locating health services closer to where they are needed by older populations. The top policy priorities that emerged from this exercise related to environmental issues, but not population per se.

\section{Comparing Canada, Korea, and Japan}

Four differences stand out. First, the degree of ethnic diversity among seniors in Canada compared to Korea and Japan. Recent data reveal that $28.4 \%$ of the population now aged $65+$ in Canada were born outside Canada (Durst, 2008). Almost $31 \%$ of foreign-born Canadians originating in Europe are now older than 65 . The older populations from east and southern Asia and Africa are growing rapidly. The policy challenges of these trends 
are unknown, but clearly Canada, as a multicultural society with large influxes of new immigrants, faces different policy challenges than do countries with limited multiculturalism and fewer recent immigrants, such as Japan and Korea. Among the challenges is the urgent need to recognize foreign credentials for more rapid and full labour market integration of immigrants. This may have some resonance with the difficulties other new or re-entering workforce entrants experience, which in turn relates to issues of delayed life transitions for youth. Immigration has served Canada well in quality of life, global capacities, and also, in part, as a means of bringing skilled labour into the country. Canada's absorptive capacity for the skills of recent immigrants has been less than impressive, however. It is difficult to worry about labour shortages due to demographic aging when highly skilled immigrants are not being employed to full capability.

The second major difference between Canada as an aging and diversifying society and Japan and Korea relates to gender and the positioning of women in the paid labour market and in familial systems. In Canada, more women, including mothers of young children, participate in the paid labour market than in either Korea or Japan. This means, on the one hand, greater contributions to taxes and pensions. On the other, it means more challenges with working outside the home at the same time as caring for young and old.

A third difference goes to the heart of the question posed in this paper: How does the framing of knowledge about demographic, family, and work change relate to capacities to act in terms of policy? The lesson of Korea suggests that economic and demographic antinatalist measures offer a country with limited old age dependency, a window, or a demographic bonus period, during which "ramping up" of the policy engine is possible. In this sense, demographic knowledge has been productive of policy action for Korea. Favourable demographics, combined with framing of that knowledge as action, in large part explains the gold standard of growth Korea has seen. Demographics may not be destiny but certainly can help at a propitious moment in economic development. As Greenhalgh (1988) astutely observes, there need not be an actual economic achievement to transform family size intentions or behaviours, it can be the knowledge of realistically accessible mobility channels. These realistically accessible mobility paths are manifested in the dramatic increases in school enrolments in Korea over the past three decades, as shown in the table below. Knowledge, again, this time at the familial level, becomes action.

\begin{tabular}{llll}
\multicolumn{4}{l}{ Proportion of school-eligible age cohort } \\
\hline \hline Enrolled in school & 1965 & 1980 & 1995 \\
South Korea & 35 & 76 & 96 \\
\hline
\end{tabular}

Source: McNicholl, Geoffrey, 2006: 14. 
The fourth difference is much larger and relates to shifting geopolitics. Globalization can be seen as eroding the capacities of national governments to make policies that are sustainable and effective. Many argue that this erosion of state capacity is now happening at a galloping rate. Witness, for example, the degree to which, in all three countries under examination here, the global economy plays a role. In the case of both Japan and Korea, global economic forces have transformed their economic situations and their economic crises since the early 1990s. At present, the shakiness of the U.S. economy, created by the subprime loan debacle; the waning of American manufacturing; and the mountains of public and private debt in the U.S., is being felt in all three countries. Canada's economy, although on much firmer ground than that of the U.S., with no deficit and a stronger currency on the global market, is nonetheless deeply linked with the U.S. economy. Consideration of any policy challenges for the future, including demographic aging and increasing diversity, must be put centrally in economic, affordability terms.

As a New York Times Magazine feature article recently put it succinctly, "Asia is shaping the world's destiny" (Khanna, 2008:62). Asia has the most people and the greatest capacity for innovation in the "grand Western narrative" of development and achievement, as both the postwar Japanese and the recent Korean success stories clearly reveal. If the web of globalization has three spiders, as Khanna's evocative imagery suggests - the American, the European, and the Chinese - the geopositioning and economic positioning of both Europe (the EU) and China puts them ahead of America which is no longer as connected, and certainly far more precarious economically, than the other two "spiders." Canada, although decidedly and firmly not the U.S., is in the ambit of the American sphere both geographically and economically. It is active, however, as a Pacific Rim country, in developing increasingly strong links with Asia. That said, current problems in the American economy could have implications for Canada as well as for the rest of the world in the future.

\section{Conclusion}

Three countries with differing configurations of markets, states, and families, and at different stages in demographic aging, Canada, Korea, and Japan have been compared and contrasted to ascertain how the conundrum of demographic aging and policy challenges may be illuminated. We have found that key differences among advanced societies' approaches to policy action may not emanate from demographic aging or from the organization 
of welfare regimes, but from how markets, states, families, and communities interact at different stages in the demographic transition, to produce and to distribute the benefits of society.

A tension exists between socioeconomic contextual factors and social policies related to demographic aging. Globalization may not be new but the increasing international flow of economic control, capital, information, and to some extent, jobs, is new in its pace and impact. Canada, Japan, and Korea have all been faced, as states, with contradictory pressures and roles: to promote global competitiveness and adjustment, and simultaneously, to protect workers, seniors, the vulnerable, communities, and industries against new threats to well-being and sustainability. Some have suggested that there has been a "fiscalization" of policy discourse. Even with the contrasting family and gender dimensions of policy challenges in the three countries, the issues of economic globalization emerge as a dominant context for policy development in relation to demographic aging.

\section{References}

American Association of Retired Persons (AARP). 2007. Perspectives of Employers, Workers and Policymakers in the G7 Countries on the New Demographic Realities. Washington, DC: AARP.

Bernard, Paul and Susan McDaniel et al. 2006. "Capturing the life course: The contribution of a panel study of life course dynamics (PSLD) to public policy analysis in Canada." A report submitted to Human Resources and Social Development Canada by an Academic Working Group.

Boling, Patricia. 1998. "Family policy in Japan.” Journal of Social Policy 27:173-190.

Bowlby, Jeffrey. 2007. "Defining retirement.” Perspectives on Labour and Income 8:15-19.

Canada, Policy Research Initiative. 2005. Population Aging and Labour Market Reforms in OECD Countries: Key Insights for Canada. Ottawa: Policy Research Initiative.

Cheal, David, ed., Aging and Demographic Change in Canadian Context. Toronto: University of Toronto Press

Choi, Eunyoung. 2008a. "Changes in carework in Korea." Paper presented at Conference, Rethinking Citizenship in the Post-Neoliberal Era, Kyoto University, February 2008.

- 2008b. "New social risks in Korea: Balancing work, family, income polarization." Paper presented at the Trilateral Social Policy Research Conference, Health Care, WorkFamily Responsibilities and Income Redistribution in Diversified and Aging Societies. Tokyo, Japan, February 16-17, 2008.

Clement, Wallace. 2001. "Who works? Comparing labour market practices.” In Janeen Baxter and Mark Western, eds., Reconfigurations of Class and Gender. Stanford, CA: Stanford University Press. 
Durst, Douglas. 2008. "More snow on the roof.” The Bridge, Metropolis Project. January issue.

Greenhalgh, Susan. 1988. "Fertility as mobility: Sinic transitions." Population and Development Review 14(4):629-674.

Ikeda, Satoshi. 2002. Trifurcating Miracle: Corporations, Workers, Bureaucrats and the Erosion of Japan's National Economy. London and New York: Routledge.

2004. "Japan and the changing regime of accumulation: A world-system study of Japan's trajectory from miracle to debacle." Journal of World-systems Research $\mathrm{X}(2): 363-394$.

2007. "Beyond competition: A Polanyian examination of Japan in crisis." Paper presented at Japan Studies Association of Canada Conference, August 2007, York University.

Ikeda, Satoshi and Jinhwan Kim. 2000. "South Korea and Canada entering the 21st century: US hegemonic revival and the end of national economic sovereignty." Korean Review of Canadian Studies 5:1-36.

Japan Statistics Office. 2008. www.stat.go.jp. Accessed 25 November 2008.

Khanna, Parag. 2008. "Waving Goodbye to Hegemony," New York Times Magazine January 27, 2008: 34-41, 62-67.

Kohler, H-P, F. Billari, and J.A. Ortega. 2002. "The emergence of the lowest low fertility in Europe during the 1990s." Population and Development Review 28(4):641-680.

Kwon, Soonman. 2008. "Health care and income of the elderly in Korea." Paper presented at the Trilateral Social Policy Research Conference, Health Care, Work-Family Responsibilities and Income Redistribution in Diversified and Aging Societies, Tokyo, Japan, February 16-17, 2008.

Leonard, Jeremy, Christopher Ragan, and France St_Hilaire, eds. 2007. A Canadian Priorities Agenda: Policy Choices to Improve Economic and Social Well-Being. Montreal: The Institute for Research on Public Policy.

Mannheim, Karl. 1952. Essays in the Sociology of Knowledge. London: Routledge.

McDaniel, Susan A. 1987. "Demographic aging as a guiding paradigm in Canada's welfare state.” Canadian Public Policy 13(3):330-336.

- 2002. "Intergenerational interlinkages: Public, work and family." Pp. 22-71 in David Cheal, ed., Aging and Demographic Change in Canadian Context. Toronto: University of Toronto Press.

- 2005. "Canada: A report on the demographic situation and policy implications." Demographic Challenges of the 21st Century. Stockholm, Sweden, 7-8 June 2005.

McMullin, J.A., M. Cooke, with R. Downie. 2004. Labour Force Aging and Skills Shortages in Canada and Ontario (CPRN Research Report WI24). Ottawa: Canadian Policy Research Networks. http://www.cprn.org/en/doc.cfm?doc $=1088$

McNicoll, Geoffrey. 2006. "Policy lessons of the East Asian demographic transition." Population Council Paper No. 210. New York: Population Council.

Myles, John. 2007. "Postponed adulthood: Dealing with the new economic inequality." Canada Council on Social Development, New Social Architecture Series. 
National Institute of Aging. 2007. Why Population Aging Matters: A Global Perspective. Washington, DC: National Institute of Aging.

Ochiai, Emiko. 2005. "The postwar Japanese family system in global perspective: Familism, low fertility, and gender roles.” Tokyo: Josai International Center for the Promotion of Arts and Sciences, Josai University.

2008. "Comparing childcare networks in Asia: Implications on gender and social policy in Japan." Paper presented at Conference, Rethinking Citizenship in the PostNeoliberal Era, Kyoto University, February 2008.

Ogata, Hiroya. 2008. "Reorganizing health care systems in diversified and aging societies." Paper presented at the Trilateral Social Policy Research Conference, Health Care, WorkFamily Responsibilities and Income Redistribution in Diversified and Aging Societies, Tokyo, Japan, February 16-17, 2008.

Organization for Economic Cooperation and Development (OECD). 2005. Society at a Glance: OECD Social Indicators. Paris: OECD.

2007. Factbook: Economic, Environmental and Social Statistics. Paris: OECD

2008. "Aging and employment policies: Average effective ages at retirement, 1970 2005.” http://www.oecd.org/dataoecd/3/1/39371913.xls. Accessed 25 November 2008

Peng, Ito. 2008. Discussant comments at conference, Rethinking Citizenship in the Post-Neoliberal Era, Kyoto University, February 2008.

Praeger, Joel. 2002. "Aging and productivity: What do we know?" Pp. 133-189 in David Cheal, ed., Aging and Demographic Change in Canadian Context. Toronto: University of Toronto Press.

Seol, Dong-Hoon. 2008. "Immigration and multiculturalism in Korea." Paper presented at the Trilateral Social Policy Research Conference, Health Care, Work-Family Responsibilities and Income Redistribution in Diversified and Aging Societies, Tokyo, Japan, February 16-17, 2008.

Shirahase, Sawako. 2008. "Changes in family structure and income inequality in Japan." Paper presented at the Trilateral Social Policy Research Conference, Health Care, WorkFamily Responsibilities and Income Redistribution in Diversified and Aging Societies. Tokyo, Japan, February 16-17, 2008.

Shorto, Russell. 2008. “No babies?” New York Times Magazine. June 29:35-41.

Statistics Canada. 2002. "2001 census: Marital status, common law status, families, dwellings and households." The Daily 22 October. 2006a. "Fleeing the parental nest." The Daily 1 August. 2006b. "Returning to the parental home." The Daily 3 October.

2006c. "Women in Canada: Work chapter updates." Ottawa: Statistics Canada, Catalogue no. 89F0133XWE.

2007a. "Canada's population by age and sex, as of July 1, 2007." The Daily

November.

2007b. "Study: Participation of older workers, 2006." The Daily 24 August.

2007c. "Returning to work after childbirth." The Daily 19 December.

2007d. "A portrait of seniors.” Ottawa: Statistics Canada, Catalogue No. 89-519-XWE. 2008. "Pension plans in Canada." The Daily 4 July. 
Stehr, Nico and Volker Meja. 2000. The Sociology of Knowledge. Cheltenham, UK: Edward Elgar.

US Census Bureau, International Data Base. 2008. http://www.census.gov/ipc/www/idb/country/caportal.html. Accessed 25 November 2008.

Véron, Jacques and Sophie Pennec. 2007. "Demographic context of the social contract in developed countries: Unity and diversity.” Pp. 45-58 in Jacques Véron, Sophie Pennec and Jacques Légaré, eds., Ages, Generations and the Social Contract: The Demographic Challenges Facing the Welfare State. Dordrecht, The Netherlands: Springer.

Weber, Max. 1949. The Methodology of Social Science. New York: The Free Press.

Zeng, Y., A. Coale, M.K. Choe, Z. Liang, and L. Liu. 1992. "Leaving parental home: Censusbased estimates for China, Japan, South Korea, United States, France, and Sweden." New Haven, CT: Yale University, Economic Growth Center, Discussion Paper, No. 673. 
